\title{
Bioaugmentation with an acetate-type fermentation bacterium Acetobacteroides hydrogenigenes improves methane production from corn straw
}

\author{
Jie Zhang a,b,1, Rong-Bo Guo ${ }^{\mathrm{a}, 1}$, Yan-Ling Qiu ${ }^{\mathrm{a}, *}$, Jiang-Tao Qiao ${ }^{\mathrm{a}}$, Xian-Zheng Yuan ${ }^{\mathrm{a}}$, Xiao-Shuang Shi ${ }^{\mathrm{a}}$, \\ Chuan-Shui Wang ${ }^{\mathrm{a}}$
}

a Shandong Industrial Engineering Laboratory of Biogas Production and Utilization, Key Laboratory of Biofuels, Qingdao Institute of Bioenergy and Bioprocess Technology,

Chinese Academy of Sciences, Qingdao 266101, Shandong, PR China

${ }^{\mathrm{b}}$ University of Chinese Academy of Sciences, Beijing 100049, PR China

\section{H I G H L I G H T S}

- A. hydrogenigenes is an acetate-type bacterium with high hydrogen yields.

- Bioaugmentation potential of $A$. hydrogenigenes was investigated.

- Addition of $A$. hydrogenigenes improved methane yield by $19-23 \%$ from corn straw.

- A. hydrogenigenes could increase cellulose and hemicelluloses removal rates.

\section{A R T I C L E I N F O}

\section{Article history:}

Received 29 September 2014

Received in revised form 6 December 2014

Accepted 8 December 2014

Available online 13 December 2014

\section{Keywords}

Anaerobic digestion

Bioaugmentation

Corn straw

Methane

Acetobacteroides hydrogenigenes

\begin{abstract}
A B S T R A C T
The effect of bioaugmentation with an acetate-type fermentation bacterium in the phylum Bacteroidetes on the anaerobic digestion of corn straw was evaluated by batch experiments. Acetobacteroides hydrogenigenes is a promising strain for bioaugmentation with relatively high growth rate, hydrogen yields and acetate tolerance, which ferments a broad spectrum of pentoses, hexoses and polyoses mainly into acetate and hydrogen. During corn straw digestion, bioaugmentation with A. hydrogenigenes led to $19-23 \%$ increase of the methane yield, with maximum of $258.1 \mathrm{~mL} / \mathrm{g}$-corn straw achieved by $10 \%$ inoculation (control, $209.3 \mathrm{~mL} / \mathrm{g}$-corn straw). Analysis of lignocellulosic composition indicated that $A$. hydrogenigenes could increase removal rates of cellulose and hemicelluloses in corn straw residue by $12 \%$ and 5\%, respectively. Further experiment verified that the addition of A. hydrogenigenes could improve the methane yields of methyl cellulose and xylan (models for cellulose and hemicelluloses, respectively) by $16.8 \%$ and $7.0 \%$.
\end{abstract}

(c) 2014 Elsevier Ltd. All rights reserved.

\section{Introduction}

Anaerobic digestion (AD) has been widely applied for the treatment of wastewater and biodegradable solid wastes, such as municipal sewage sludge, kitchen waste and animal manures. Agricultural residues are abundant and sustainable renewable natural resources in nature, which are attractive feedstock for anaerobic digestion due to its abundance, low production costs, high polysaccharide content and methane yield. However,

\footnotetext{
* Corresponding author at: Key Laboratory of Biofuels, Qingdao Institute of Bioenergy and Bioprocess Technology, Chinese Academy of Sciences, No. 189 Songling Road, Qingdao 266101, Shandong Province, PR China. Tel./fax: +86 532 80662750.

E-mail address: qiuyl@qibebt.ac.cn (Y.-L. Qiu).

1 These authors contributed equally to this work.
}

currently the efficiency of anaerobic technology in treating lignocellulosic biomass to methane is limited. Since methane production are attributed to the activity and stability of the anaerobic microbial populations. Amounts of attention on improvement strategies for anaerobic digestion have presently been paid to design and optimize the complex microbial consortia responsible for lignocellulosic biomass degradation. Bioaugmentation is a feasible strategy for pollutant removal and site remediation, which introduces specific microorganisms to the local population. The technology has been applied in agriculture and in wastewater treatment for many years. Currently, the most successful cases of bioaugmentation occur in confined systems, such as bioreactors in which the conditions can be controlled to favor survival and prolonged activity of the exogenous microbial population (Fantroussi and Agathos, 2005; Gentry et al., 2004). 
Lignocellulosic biomass mainly consists of lignin (5-25\%) and carbohydrate polymers (cellulose, 35-45\%; hemicelluloses, 25$40 \%$ ), which are associated with each other (Klinke et al., 2003). Under methanogenic conditions, lignin is resistant to anaerobic degradation, while cellulose and hemicelluloses could be converted into more readily fermentable mono-, di- and oligo-saccharides. Therefore, enhancing the degradation efficiency of the cellulose and hemicelluloses is one of the key factors to facilitate methane production. Stable anaerobic digestion of organic waste is accomplished by four important stages: hydrolysis, acidogenesis, acetogenesis and methanogenesis. Cellulose is hydrolyzed into glucose, and hemicelluloses is hydrolyzed into pentoses (xylose and arabinose), hexoses (mannose, glucose and galactose) and sugar acids by hydrolytic-fermentative bacteria (Hendriks and Zeeman, 2009). Pentoses and hexoses are further degraded mainly via five fermentation pathways: acetate-type, butyrate-type, propionatetype, ethanol-type and lactate-type fermentation, with the products of propionate, butyrate, acetate, ethanol, lactate, $\mathrm{H}_{2}$, etc. (Jayasinghearachchi et al., 2009; McDonald and Edwards, 1976). During $\mathrm{AD}$ process, the conversion rates of volatile fatty acids (VFAs) to methane varies in the order of acetate $>$ ethanol > butyrate $>$ propionate (Wang et al., 2009). Moreover, acetate is normally the most concentrated of carboxylic acids but is less inhibitory to methanogens than propionate and butyrate (Mösche and Jördening, 1999). Compared to other fermentation pathways, hydrogen producing acetate-type fermentation has advantage for methane yield as the equation described: $\mathrm{C}_{6} \mathrm{H}_{12} \mathrm{O}_{6}+2 \mathrm{H}_{2} \mathrm{O} \rightarrow 4 \mathrm{H}_{2}+2 \mathrm{CO}_{2}+2 \mathrm{CH}_{3} \mathrm{COOH}$, since its products of $\mathrm{H}_{2} / \mathrm{CO}_{2}$ and acetate could be directly converted into methane by methanogens. It is therefore obvious that acetate-type fermentation bacteria seem to be promising microorganisms for increasing methane production. Currently, most investigations are focused on cellulolytic or hemicellulolytic bacteria as enhanced microorganisms for anaerobic digestion, and no studies on hydrogen producing, acetate-type microorganisms for the bioaugmentation of lignocellulosic biomass as sole feed stock (Akila and Chandra, 2010; Lü et al., 2013; Nielsen et al., 2007; Peng et al., 2014; Wei $\beta$ et al., 2010).

In anaerobic crop residues treatment, a high abundance of Bacteroidetes organisms are frequently detected; they are considered to be of high relevance for the degradation of complex polysaccharides (Qiao et al., 2013; Wang et al., 2010; Yan et al., 2012). In this study, growth, hydrogen production characteristics, and bioaugmentation potential of a hydrogen producing acetate-type bacterium Acetobacteroides hydrogenigenes in the phylum Bacteroidetes for $\mathrm{AD}$ of corn straw were described.

\section{Methods}

\subsection{Raw material and substrates}

Corn straw used in this study was naturally harvested and sundried, smashed to approximately $1-3 \mathrm{~mm}$ pieces using a grinder. The straw was dried at $105^{\circ} \mathrm{C}$ for $12 \mathrm{~h}$ to a constant weight before experiments, which contained $93.3 \%$ total solids (TS), of which $36 \%$, $30 \%$ and $6 \%$ were cellulose, hemicelluloses and lignin respectively. Kraft lignin (KL), methyl cellulose (MC) and xylan were purchased from SIGMA.

\subsection{Inoculum, bioaugmentation microorganisms and preparation of cell suspension}

Bioaugmentation was performed in batch experiments inoculated with adapted biogas slurry taken from a full-scale mesophilic $\left(35^{\circ} \mathrm{C}\right)$, anaerobic completely stirred tank reactor (CSTR) (volume,
$500 \mathrm{~m}^{3}$ ) feeding with untreated corn straw as the sole feedstock for more than one year (Qiao et al., 2013). Biogas slurry (2 L) was suspended with $2 \mathrm{~L}$ sterile distilled water in a $20 \mathrm{~L}$ tank. Then, solid content was separated from slurry by filter cloth. To assure that solid content in solution were dominated by bacteria, solution obtained then be filtered by 315 micron cartridge. The suspension solution was then centrifuged at $8000 \mathrm{rpm}$ for $10 \mathrm{~min}$, and the pellets were collected and resuspended in blank medium without substrate. The total solid (TS) and volatile solid (VS) content of methanogenic inoculum were $5 \%$ and $60 \%$, respectively. The medium used for cultivation, hydrogen production characteristics and bioaugmentation was prepared as described previously (Sekiguchi et al., 2000).

A. hydrogenigenes (DSM 24657) used for bioaugmentation was originally isolated from a reed swamp (Su et al., 2014). Terrimicrobium sacchariphilum (JCM 17479) and Clostridium pascui (DSM 10365) were used as control bacteria: T. sacchariphilum was originally isolated from rural rice paddy field (Qiu et al., 2014), and C. pascui was obtained from DSMZ (Deutsche Sammlung von Mikroorganismen und Zellkulturen $\mathrm{GmbH}$, Braunschweig, Germany) (Wilde et al., 1997). Main characteristics of the three anaerobic bacteria were listed in Table S1. A. hydrogenigenes and T. sacchariphilum were maintained on $10 \mathrm{mM}$ glucose medium, and growth was observed within 2-4 days of incubation at $37^{\circ} \mathrm{C}$. Glutamate $(2 \mathrm{mM})$ and yeast extract $(0.01 \%)$ were used to cultivate $C$. pascui at $37^{\circ} \mathrm{C}$. For bioaugmentation experiment, the cells were harvested at logarithmic phase. The bacterial suspensions were centrifuged at $8000 \mathrm{rpm}$ for $15 \mathrm{~min}$, and the pellets were collected and resuspended in blank medium.

\subsection{Evaluation of growth and hydrogen production characteristics of A. hydrogenigenes}

Growth and hydrogen production characteristics of $A$. hydrogenigenes were evaluated by batch experiment. Metabolism of glucose by $A$. hydrogenigenes in pure culture and co-culture with a hydrogenotrophic methanogen Methanospirillum hungatei (DSM 864 ) was determined with $3 \mathrm{mM}$ glucose and $0.01 \%$ yeast extract (inoculum size, $5 \%, \mathrm{v} / \mathrm{v}$ ). The influence of glucose concentrations on the growth of $A$. hydrogenigenes in pure culture and co-culture with $M$. hungatei was checked in the range of 1.2-38 g/L glucose. The effect of acetate on the growth of pure culture of $A$. hydrogenigenes was checked in the medium containing $1.3 \mathrm{mM}$ glucose. Initial sodium acetate $(10,20,50,100,150,200 \mathrm{mM})$ was added respectively. The control test was conducted without sodium acetate addition. To test the effect of hydrogen on the growth of $A$. hydrogenigenes in pure culture and co-culture with M. hungatei, $101 \mathrm{kPa}$ mixture of hydrogen, carbon dioxides and nitrogen $\left(\mathrm{H}_{2} / \mathrm{CO}_{2} /\right.$ $\mathrm{N}_{2}=3 / 1 / 1, \mathrm{v} / \mathrm{v}$ ) was used to sparge the headspace of the serum vials containing $3 \mathrm{mM}$ glucose medium at the start of the experiments. Except otherwise described, all experiments were conducted with 60 -mL (liquid volume, $20 \mathrm{~mL}$ ) serum vials in triplicate at $37^{\circ} \mathrm{C}$, with exponential-phase pure culture of $A$. hydrogenigenes grown on glucose medium as the inoculum $(10 \%, v / v)$. The growth of cells was determined visually by observing turbidity and the increase in $\mathrm{OD}_{600}$, monitoring glucose depletion, hydrogen and acetate production. The growth rate of cells was evaluated based on the production of hydrogen (or methane for the co-cultures).

\subsection{Bioaugmentation experiments}

To investigate the bioaugmentation potential of $A$. hydrogenigenes on corn straw biodegradation (TS, 1\%), batch experiments were carried out in $300 \mathrm{~mL}$ (liquid volume, $120 \mathrm{~mL}$ ) serum vials under an atmosphere of $\mathrm{N}_{2}: \mathrm{CO}_{2}(80: 20, \mathrm{v} / \mathrm{v})$ at $37{ }^{\circ} \mathrm{C}\left(\mathrm{pH}_{25^{\circ} \mathrm{C}} 7.0\right)$ with anaerobic slurry as inoculum (inoculum size, $10 \%, \mathrm{v} / \mathrm{v}$ ) 
without shaking. Furthermore, to investigate the role of A. hydrogenigenes during corn straw degradation, methyl cellulose (MC), kraft lignin (KL), and xylan were used as models for cellulose, lignin and hemicelluloses, respectively. The effect of A. hydrogenigenes on anaerobic degradation of MC, KL and xylan was designed in a similar manner to that of corn straw digestion. Except that the experiment was carried out in $60 \mathrm{~mL}$ (liquid volume, $20 \mathrm{~mL}$ ) serum vials. Each experiment was performed in triplicate. The TS, contents of cellulose, hemicelluloses and lignin of corn straw were measured before and after the degradation assay. Methane production was measured periodically.

\subsubsection{Bioaugmentation of A. hydrogenigenes into the biogas slurry to} enhance corn straw biodegradation

To determine the bioaugmentation potential of hydrogen producing acetate-type fermentation bacterium on corn straw biodegradation, A. hydrogenigenes was used as an enhanced organism. A propionate-type bacterium $T$. sacchariphilum and an anaerobic amino acids fermenting bacterium $C$. pascui were used as the control bacteria. A total volume of $200 \mathrm{~mL}$ of pure cultures were collected by centrifugation at $8000 \mathrm{rpm}$ for $15 \mathrm{~min}$ at $35^{\circ} \mathrm{C}$, and resuspended in blank medium to give the same $\mathrm{OD}_{600}$. The cell suspension was then inoculated into two kinds of bottles containing medium supplemented with either (i) corn straw and biogas slurry, or (ii) biogas slurry with no addition of corn straw as control test, respectively (inoculum size: $10 \%, \mathrm{v} / \mathrm{v}$ ). In addition, two other sets of control experiments were performed to evaluate corn straw degradation without bioaugmentation and endogenous methanogenic activity of the slurry itself: (i) corn straw and biogas slurry, (ii) biogas slurry. In the calculation of methane production, the methane yields were corrected by subtracting the amount of methane formed in the control experiments accordingly. Effect of different inoculation ratios (5\%, $10 \%$ and $20 \%$ ) of A. hydrogenigenes on methane production from corn straw was designed in a similar manner as described above.

2.4.2. Effect of A. hydrogenigenes on anaerobic degradation of $M C, K L$ and xylan

To investigate the mechanism of $A$. hydrogenigenes on the bioaugmentation of corn straw degradation, batch experiments were performed with three models of cellulose, lignin and hemicelluloses of corn straw as sole substrates. Bioaugmentation of methyl cellulose (MC), kraft lignin (KL), and xylan (each $0.1 \%$, w/v) degradation by $A$. hydrogenigenes was tested similarly with that of the corn straw (see Section 2.4.1.). The inoculum size of $A$. hydrogenigenes was set in $10 \%(\mathrm{v} / \mathrm{v})$.

\subsection{Analytical methods}

The contents of cellulose, hemicelluloses and lignin before and after corn straw digestion were measured according to Georing and Van Soest (1970). SCOD, TS, VS and pH were measured according to the standard methods (SEPA, 2002). Glucose concentration was determined by a glucose biosensor with a glucose oxidaseimmobilized membrane (SBA-40D, Biology institute of Shandong Academy of sciences, Shandong province, China). The gas composition and acetate concentration were analyzed by a gas chromatograph as described previously (Yuan et al., 2011).

\subsection{Data analysis}

Data were presented as mean \pm standard deviation (SD). Oneway analysis of variance (ANOVA) followed by Duncan's multiple range tests were performed for mean separations. SPSS for windows (SPSS Inc. Chicago, version 16.0) was used for all statistical analysis and $P$ values $<0.05$ were considered significant.

\section{Results and discussion}

3.1. Evaluation of growth and hydrogen production characteristics of A. hydrogenigenes

A. hydrogenigenes is an anaerobic, hydrogen producing bacterium belonging to Bacteroidetes isolated from a reed swamp ( $\mathrm{Su}$ et al., 2014). The main characteristics of $A$. hydrogenigenes and control strains were summarized in Table S1. A. hydrogenigenes could degrade various substrates, including hexoses, pentoses, oligose, polyoses, tryptone and yeast extract. Prior to bioaugmentation study, growth and hydrogen production characteristics of $A$. hydrogenigenes were investigated to determine its potential for bioaugmentation. Initial substrate and products concentrations play an important role on the growth and production rates of the hydrogen, and high substrate or products concentrations may have an inhibition on fermentation (Argun et al., 2009; Fabiano and Perego, 2002; Jayasinghearachchi et al., 2009). Therefore, the effects of glucose, liquid and gaseous end products on the growth and hydrogen production of $A$. hydrogenigenes were determined by varying their initial concentrations in the medium.

A. hydrogenigenes produced acetate and hydrogen as the main fermentation products from glucose ( $1 \mathrm{~mol}$ of glucose was converted to approximately $1.9 \mathrm{~mol}$ of acetate and $4.2 \mathrm{~mol}$ of hydrogen, electron recovery: 99\%) (Fig. 1a and b). The actual degradation and products formation were nearly equivalent to the theoretical stoichiometry (Equation: $\mathrm{C}_{6} \mathrm{H}_{12} \mathrm{O}_{6}+2 \mathrm{H}_{2} \mathrm{O} \rightarrow 4 \mathrm{H}_{2}+2 \mathrm{CO}_{2}+2 \mathrm{CH}_{3} \mathrm{COOH}$ ). The influence of initial glucose concentration on the growth of $A$. hydrogenigenes by pure culture and co-culture was shown in Fig. 1. Although A. hydrogenigenes produced hydrogen, its growth was not stimulated in co-cultivation with M. hungatei, suggesting that the growth of the strain may be slightly affected by hydrogen produced (Fig. 1a and b). However, the presence of M. hungatei could considerably increase the efficiency of glucose degradation in a certain concentration range: i.e., $1.2-1.5 \mathrm{~g} / \mathrm{L}$ glucose was almost completely degraded by the co-culture, while $60 \%$ degraded by pure culture (Fig. 1c and d). The strain grew well and kept a high hydrogen (or methane) yield within a wide range of initial glucose concentrations for both pure culture and co-culture (up to $38 \mathrm{~g} / \mathrm{L}$ ) within one month of incubation, and the final $\mathrm{pH}$ range was 6.4-6.8 (Fig. 1c and d). The degradation rates of glucose became lower with the increase of glucose concentration. The maximal hydrogen yield was $571 \mathrm{~mL} / g$-glucose (equivalent to $4.6 \mathrm{~mol} \mathrm{H}_{2} /$ mol-glucose) at initial glucose concentration of $1.5 \mathrm{~g} / \mathrm{L}$ with $\mathrm{pH}$ 7.0. The observed hydrogen yield was $343 \mathrm{~mL} / \mathrm{g}$ glucose $\left(2.8 \mathrm{~mol} \mathrm{H}_{2} /\right.$ mol-glucose), which was corresponding to $70 \%$ of the theoretical yield with $3.8 \mathrm{~g} / \mathrm{L}$ initial glucose.

Hydrogen and carbon dioxide are the primary composition in the biogas. Hydrogen partial pressure $\left(\mathrm{pH}_{2}\right)$ in the gas phase is one of the key factors affecting hydrogen production. In general, hydrogen synthesis pathways are sensitive to hydrogen concentrations and are subject to end-product inhibition (Wang et al., 2007). The effect of $\mathrm{pH}_{2}$ on $A$. hydrogenigenes in pure culture and co-culture with $M$. hungatei was investigated. Glucose could be completely degraded at high initial hydrogen partial pressure ( $>40 \mathrm{mmol} / \mathrm{L}$ culture) by both cultures, however, the pure culture needed a longer lag period of 1-2 days before glucose consumption compared to the co-culture with M. hungatei (Fig. 2a and b). Compared with no hydrogen addition, both cultures needed a longer lag times of 3-4 days for growth when hydrogen presented (Figs. 1a, b, and $2 \mathrm{a}, \mathrm{b})$. These results further confirmed that $A$. hydrogenigenes can tolerate high hydrogen partial pressure. Moreover, the concentration of liquid product of acetate may also impact hydrogen producing bacteria. The effect of acetate on the growth of $A$. hydrogenigenes is illustrated in Fig. $2 c$. The addition of acetate up to $50 \mathrm{mM}$ only had a little inhibition $(<24 \%)$ on the growth and 

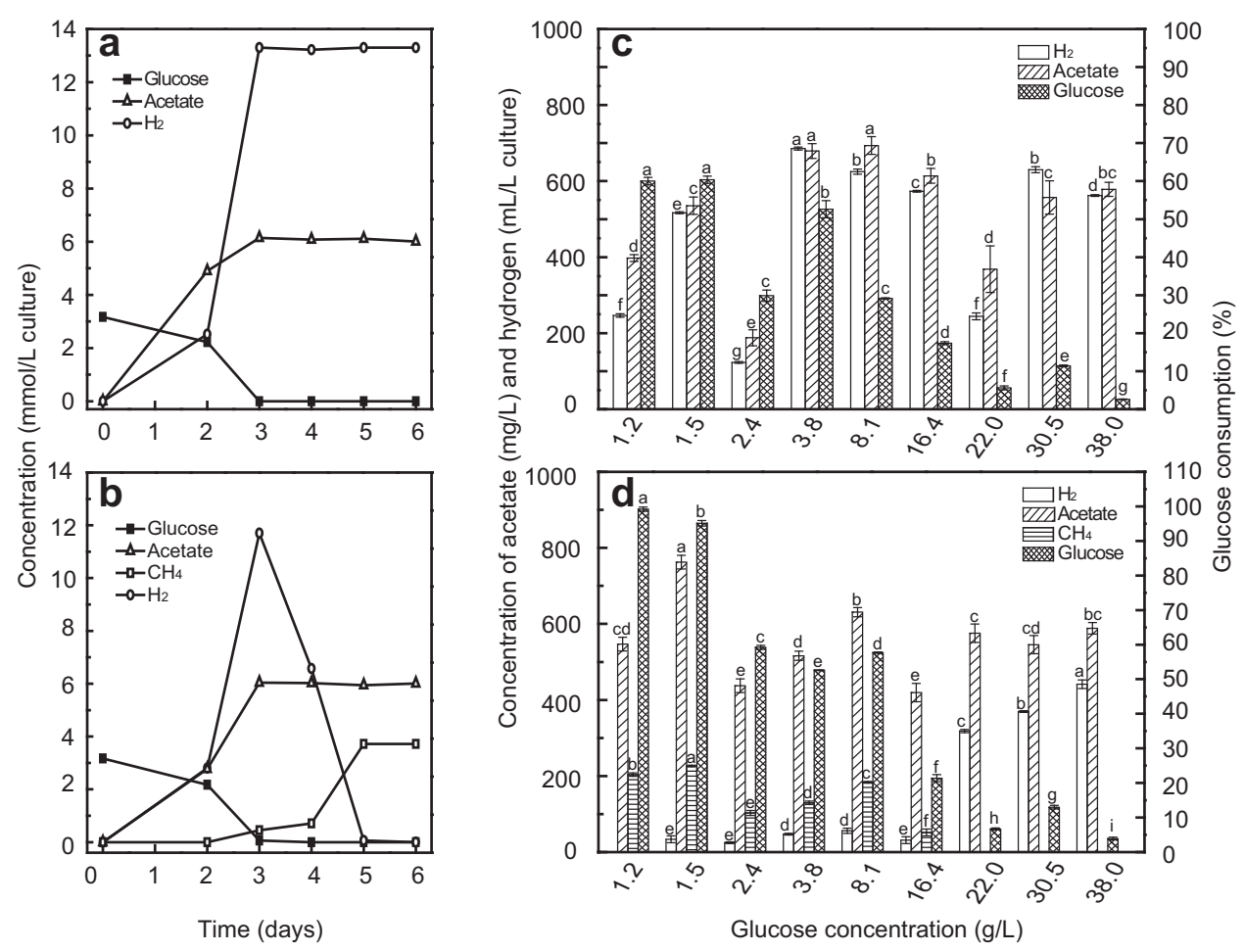

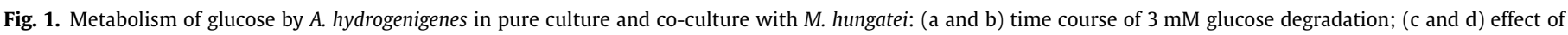
different initial glucose concentrations. Significant differences are indicated by different letters $(p<0.05)$.

glucose consumption of $A$. hydrogenigenes. 100 and $200 \mathrm{mM}$ acetate inhibited glucose degradation by $35 \%$ and $11 \%$, respectively. The high tolerance was important for maintenance microbe activity in the bioaugmentation system when high levels of saccharides, hydrogen or acetate present. It has been reported that the range of acetate concentration tends to be $0.1-100 \mathrm{mM}$ in $\mathrm{AD}$ process (Kovács et al., 2004). A. hydrogenigenes had the potential for bioaugmentation with relatively high growth rate, hydrogen yields and products tolerance.

\subsection{Effect of bioaugmentation of A. hydrogenigenes into the biogas slurry to enhance corn straw biodegradation}

To assess the effect of bioaugmentation with hydrogen-producing acetate-type bacterium $A$. hydrogenigenes into the biogas slurry, batch experiments were performed with corn straw (TS, 1\%) as the sole carbon source. A propionate-type bacterium $T$. sacchariphilum and an anaerobic amino acids fermenting bacterium $C$. pascui were selected as the control bacteria. Corn straw was converted to methane within 40 days of fermentation (Fig. 3a). Methane yields from corn straw with $A$. hydrogenigenes addition were significantly higher $(p<0.05)$ than that with control bacteria addition at days 11, 27 and 35. Addition of $A$. hydrogenigenes led to a significant increase in methane yield by $18.4 \%$. The specific methane yield was $234.6 \mathrm{~mL} / \mathrm{g}$-corn straw around day 27 in the presence of $A$. hydrogenigenes. However, with addition of control bacteria of propionate-type fermentation bacterium $T$. sacchariphilum or amino acids degrading bacterium $C$. pascui, the methane yields were 200.4 and $205.7 \mathrm{~mL} / \mathrm{g}$-corn straw respectively, which were almost the same as that of the control $(198.1 \mathrm{~mL} / \mathrm{g}$-corn straw). Based on the above results, it can be concluded that bioaugmentation with hydrogen-producing, acetate-type fermentation bacterium $A$. hydrogenigenes can improve methane yield from $\mathrm{AD}$ of corn straw.

In the $\mathrm{AD}$ process, hydrogen plays an important role in complex microbiological food chain, which is related to biogas production and process stability. Hydrogen below a certain concentration makes biogas formation become thermodynamically possible. Furthermore, methanogens need a good supply of hydrogen to carry out redox reaction (Kovács et al., 2004). Recently, several researches focused on improvement of biogas production by bioaugmentation with hydrogen-producing cellulolytic or hemicellulolytic bacteria (Bagi et al., 2007; Kovács et al., 2013). Bagi reported that mesophilic Enterobacter cloacae and thermophilic Caldicellulosiruptor saccharolyticus improved the biogas yield obviously from AD of mixtures of pig slurry, sludge and dried plant biomass inoculated with natural biogas-generating ecosystem in batch experiment. The results demonstrated that only the in situ generated $\mathrm{H}_{2}$ rather than the extra supplemented $\mathrm{H}_{2}$ was responsible for the intensification. Addition of $C$. saccharolyticus increased 60$70 \%$ biogas yield in $15 \mathrm{~m}^{3}$ anaerobic, thermophilic, complete mixing fermentor fed with pig manure slurry as substrate (Bagi et al., 2007). Kovács demonstrated that E. cloacae and C. saccharolyticus increased biogas yield $33-47 \%$ and $40-42 \%$, respectively in $5 \mathrm{~L}$ reactor fed with pig slurry and chopped sweet sorghum (Kovács et al., 2013). Combined results from this study with previous studies, it can be assumed that bioaugmentation with hydrogen-producing bacterium will be a feasible strategy for improving methane production from waste treatment.

\subsection{Effect of inoculation ratios of A. hydrogenigenes on methane production from corn straw}

To further investigate the effect of inoculation ratios of $A$. hydrogenigenes on methane yields, $A$. hydrogenigenes at 5-20\% ratios were evaluated by methane yields, TS removal rates, SCOD, cellulose, hemicelluloses and lignin in corn straw. As shown in Fig. 3b, there were significant differences between non-bioaugmentation and bioaugmentation treatments $(p<0.05)$. The maximum methane yields in inoculation ratios of $5 \%, 10 \%$, and $20 \%$ of $A$. hydrogenigenes were 249.2, 258.2, and $251.7 \mathrm{~mL} / \mathrm{g}$-corn straw respectively, 

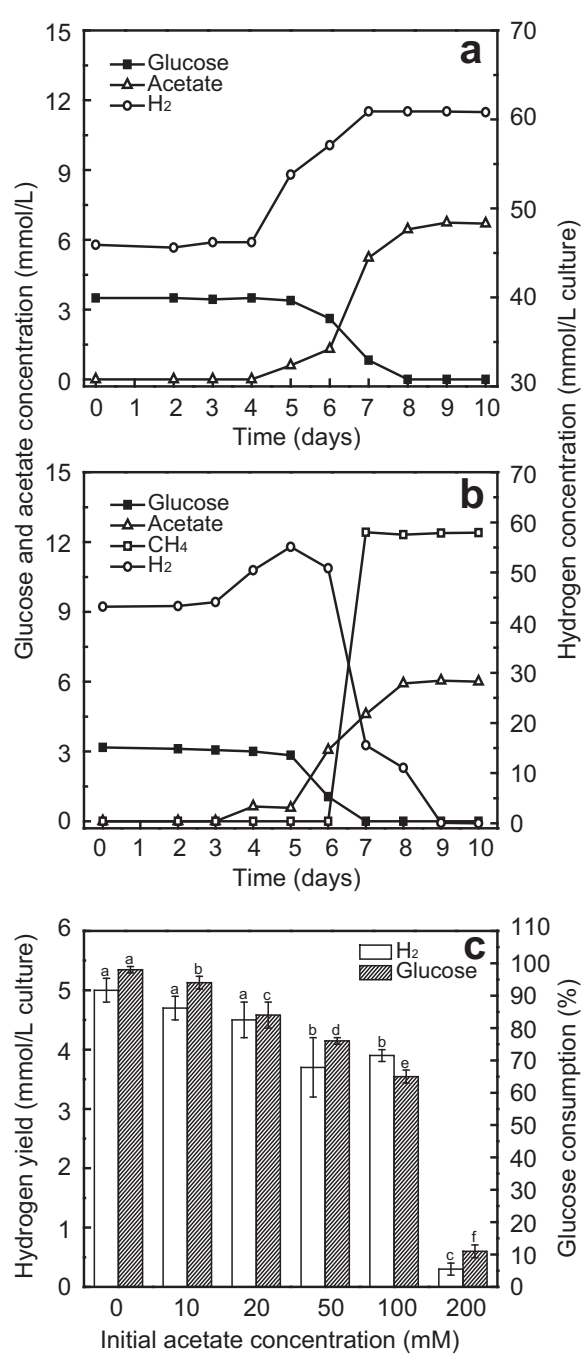

Fig. 2. Effects of hydrogen partial pressure (a and b) and different initial acetate concentrations (c) on the growth and metabolism of $A$. hydrogenigenes: (a and $c$ ) pure culture; (b) co-culture with $M$. hungatei. Significant differences are indicated by different letters $(p<0.05)$.

increasing by $19-23 \%$ compared to that of the control $(209.3 \mathrm{~mL} / \mathrm{g}$ corn straw). The methane production with $10 \%$ inoculum of $A$. hydrogenigenes was significantly higher $(p<0.05)$ than that of $5 \%$ and $20 \%$ inoculums at the end of fermentation (48-55 days), suggesting that the methane yield by bioaugmentation was not basically proportional to inoculation ratios of enhanced microorganisms. Fotidis used "microbiological domino effect" to explain the function of bioaugmentation bacteria, indicating that bioaugmentation bacteria are sufficient to establish a change in the microbial community though with a relative low abundance (Fotidis et al., 2014). Table 1 showed the values of TS removal efficiency and SCOD after degradation. The TS removal rates with $5 \%, 10 \%$ and $20 \%$ inoculation ratios of $A$. hydrogenigenes were $47.0 \%, 47.1 \%$ and $47.2 \%$, which were $5.1 \%$ higher than that of the control (44.7\%), but the experimental standard deviation (SD) was high. SCOD with $5 \%$, $10 \%$ and $20 \%$ inoculation ratios of $A$. hydrogenigenes were 1423.8 , 1152.5 and $1498.8 \mathrm{mg} / \mathrm{L}$, which was $8-29 \%$ lower than that of the control ( $1628.8 \mathrm{mg} / \mathrm{L})$. Combined with the values of methane yield, TS removal rate and SCOD, it can be hypothesized that hydrogenproducing acetate-type fermentation bacterium $A$. hydrogenigenes improved methane production of corn straw by conversion hydrolysates of cellulose and hemicelluloses to more $\mathrm{H}_{2}$ and acetate, which then be utilized by methanogens to methane.
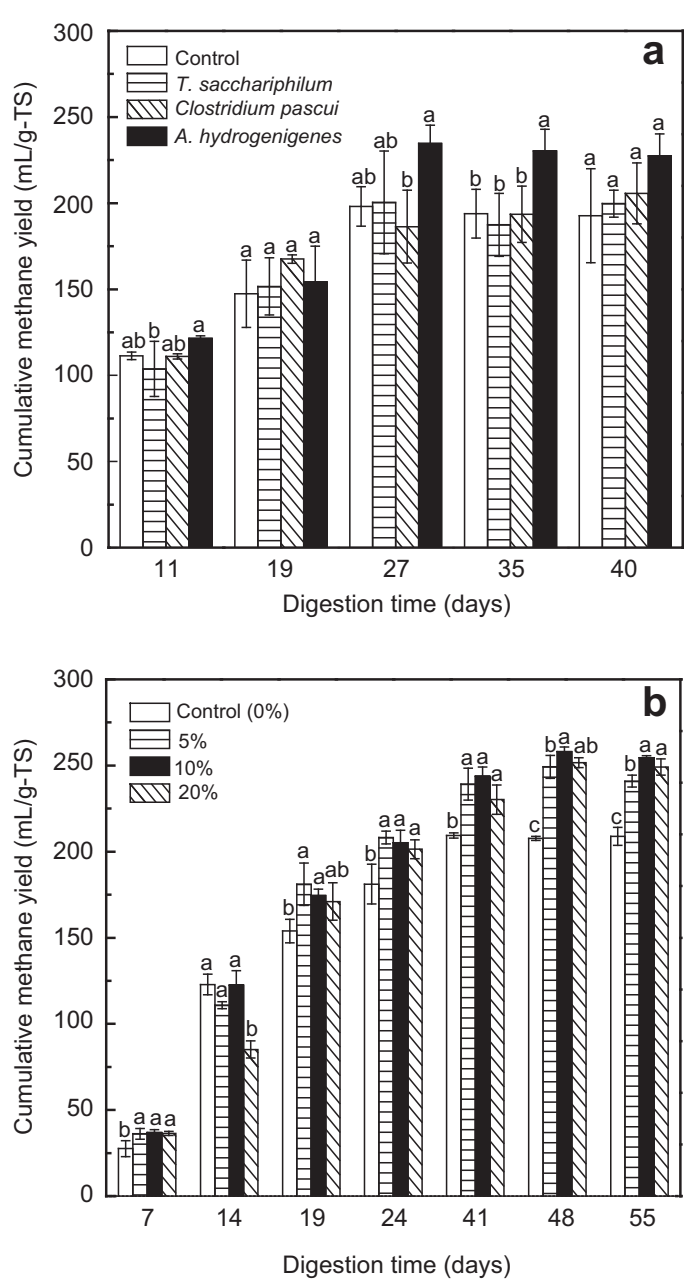

Fig. 3. Effect of bioaugmentation on the cumulative methane yield from anaerobic digestion of corn straw: (a) with A. hydrogenigenes and control bacteria $T$. sacchariphilum and Clostridium pascui; (b) different inoculum sizes of $A$. hydrogenigenes. Significant differences are indicated by different letters $(p<0.05)$.

To evaluate which components of corn straw contributed to the improvement of methane production with bioaugmentation, lignocellulosic composition of corn straw after digestion was measured (Table 1$)$. The cellulose removal rates with addition of $A$. hydrogenigenes were $76.4 \%$ (5\% inoculum), $75.4 \%$ (10\% inoculum) and $71.5 \%$ (20\% inoculum), which was $5-12 \%$ significantly higher than that of the control (68.1\%). The hemicelluloses removal rates with A. hydrogenigenes addition were $64.3 \%$ (5\% inoculum), 65.9\% (10\% inoculum) and $66.9 \%$ (20\% inoculum) respectively, which was $0.5-5.0 \%$ higher than that of the control (63.9\%). A. hydrogenigenes ferments soluble C5 and C6 sugars, di- and oligosaccharides to acetate and hydrogen, which could promote cellulose and hemicelluloses fermentation.

\subsection{Effect of A. hydrogenigenes on methane production from $M C, K L$ and xylan}

A. hydrogenigenes could improve methane production through increasing the degradation of hydrolysates of corn straw. To further demonstrate the effect of $A$. hydrogenigenes on AD of cellulose, hemicelluloses and lignin, batch experiments were conducted with kraft lignin (KL), methyl cellulose (MC) and xylan as model substrates. Xylan is the dominant component of hemicelluloses in agricultural plants such as straw (Ebringerová and Heinze, 2000). Kraft lignin was usually utilized as model of lignin component 
Table 1

Effect of A. hydrogenigenes on TS removal efficiency, SCOD and removal rates of cellulose and hemicelluloses from corn straw.

\begin{tabular}{|c|c|c|c|c|c|c|c|}
\hline \multirow[t]{2}{*}{ Inoculation ratios } & \multirow[t]{2}{*}{ TS removal efficiency $(\%)^{b}$} & \multirow[t]{2}{*}{$\mathrm{SCOD}(\mathrm{mg} / \mathrm{L})^{\mathrm{b}}$} & \multicolumn{3}{|c|}{ Lignocellulosic composition (\%) } & \multicolumn{2}{|c|}{ Degradation $(\%)^{\mathrm{b}}$} \\
\hline & & & Hemicelluloses & Cellulose & Lignin & Hemicellulose & Cellulose \\
\hline Initial point $^{\mathrm{a}}$ & - & - & $27.5 \pm 2.0 \mathrm{a}$ & $31.0 \pm 2.6 \mathrm{a}$ & $10.3 \pm 0.2 b$ & - & - \\
\hline $0 \%$ & $44.7 \pm 0.3 a$ & $1628.8 \pm 146.7 a$ & $18.0 \pm 1.9 b$ & $17.9 \pm 0.8 b$ & $17.5 \pm 0.8 a$ & $63.9 \pm 3.5 a$ & $68.1 \pm 1.2 c$ \\
\hline $5 \%$ & $47.0 \pm 2.6 a$ & $1423.8 \pm 397.8 a$ & $17.9 \pm 0.5 b$ & $13.4 \pm 1.6 c$ & $16.1 \pm 1.3 a$ & $64.3 \pm 0.7 a$ & $76.4 \pm 2.5 a$ \\
\hline $10 \%$ & $47.1 \pm 2.7 a$ & $1152.5 \pm 21.2 \mathrm{a}$ & $17.1 \pm 1.7 b$ & $13.9 \pm 1.6 c$ & $16.8 \pm 1.5 a$ & $65.9 \pm 3.3 \mathrm{a}$ & $75.4 \pm 3.4 \mathrm{ab}$ \\
\hline $20 \%$ & $47.2 \pm 1.0 \mathrm{a}$ & $1498.8 \pm 203.3 a$ & $16.6 \pm 2.0 \mathrm{~b}$ & $16.1 \pm 0.6 b c$ & $17.1 \pm 2.3 a$ & $66.9 \pm 4.7 \mathrm{a}$ & $71.5 \pm 1.2 b c$ \\
\hline
\end{tabular}

a The mixture of cornstalk and slurry before anaerobic fermentation.

b Data are shown as mean \pm standard deviation. Different letters in a single column indicate significantly difference between different inoculation ratios at $p<0.05$.

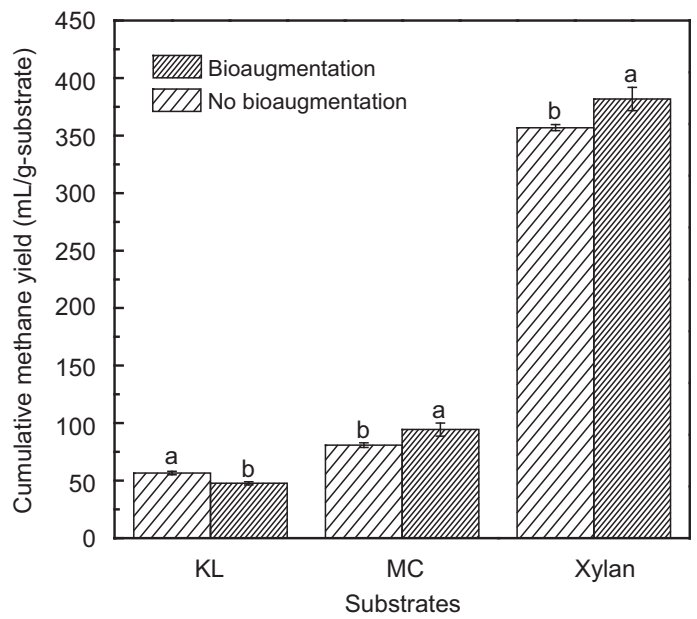

Fig. 4. Methane production from anaerobic degradation of kraft lignin (KL), methyl cellulose (MC) and xylan with addition of $A$. hydrogenigenes. Significant differences are indicated by different letters $(p<0.05)$. for anaerobic degradation (Wu and He, 2013). Significantly differences were observed $(p<0.05)$ in methane yield between non-bioaugmentation and bioaugmentation of MC, KL and xylan degradation (Fig. 4). The maximum methane production of MC with bioaugmentation was $94.4 \mathrm{~mL} / \mathrm{g}-\mathrm{MC}$, which was $16.8 \%$ higher in comparison with that of the control ( $80.9 \mathrm{~mL} / \mathrm{g}-\mathrm{MC})$. Methane production from xylan with $A$. hydrogenigenes addition reached $381.8 \mathrm{~mL} / \mathrm{g}$-xylan, $7.0 \%$ higher than that of the control $(356.8 \mathrm{~mL} /$ g-xylan). In contrast, the addition of $A$. hydrogenigenes did not improve methane yield from KL degradation. These results demonstrated that the addition of acetate-type bacterium $A$. hydrogenigenes could improve methane yields of MC and xylan but not lignin. The bioaugmentation results of MC, xylan and KL degradation were in accordance with that of corn straw degradation, suggesting that hydrogen-producing acetate-type fermentation bacterium $A$. hydrogenigenes could enhance methane production from cellulose and hemicelluloses.

This study described the effect of bioaugmentation with a hydrogen-producing acetate-type fermentation bacterium in the phylum Bacteroidetes on the AD of corn straw by adapted biogas

Table 2

Comparison of bioaugmentation on methane or biogas production from organic wastes with described species.

\begin{tabular}{|c|c|c|c|c|c|c|c|c|}
\hline \multicolumn{4}{|c|}{ Main characteristics of enhanced microorganisms } & \multicolumn{5}{|c|}{ Application in anaerobic digestion } \\
\hline Species name & Substrates range & Main products & $T\left(T_{\mathrm{opt}}{ }^{\circ} \mathrm{C}\right)$ & Feedstock & $T\left({ }^{\circ} \mathrm{C}\right)$ & Reactor type & $\begin{array}{l}\text { Increase of } \\
\text { methane } \\
\text { yield }(\%)^{\mathrm{b}}\end{array}$ & References \\
\hline $\begin{array}{l}\text { Clostridium } \\
\text { thermocellum } \\
\text { (DSM 2360) }\end{array}$ & $\begin{array}{l}\text { Cellulose, starch, } \\
\text { sugars }\end{array}$ & $\begin{array}{l}\text { Acetate, butyrate, } \\
\text { ethanol and } \mathrm{H}_{2}\end{array}$ & $38-72(43-65)$ & Microalgae & 55 & Batch & $17-24$ & Lü et al. (2013) \\
\hline $\begin{array}{l}\text { Clostridium } \\
\text { cellulolyticum } \\
\text { (DSM 5812) }\end{array}$ & Cellulose, sugars & $\begin{array}{l}\text { Acetate, ethanol, } \\
\text { lactate, formate } \\
\text { and } \mathrm{H}_{2}\end{array}$ & $25-45(32-35)$ & Wheat straw & 37 & Batch & $8-13$ & Peng et al. (2014) \\
\hline $\begin{array}{l}\text { Clostridium sp. } \\
\text { (DSM 15427) }\end{array}$ & Xylan, sugars & $\begin{array}{l}\text { Acetate, formate, } \\
\text { lactate and } \mathrm{H}_{2}\end{array}$ & $5-50(20)$ & Cattle manure & 20 & Batch & $72^{\mathrm{b}}$ & $\begin{array}{l}\text { Akila and Chandra } \\
\text { (2010) }\end{array}$ \\
\hline $\begin{array}{l}\text { Caldicellulosiruptor } \\
\text { lactoaceticus } \\
\text { (DSM 9545) }\end{array}$ & $\begin{array}{l}\text { Cellulose, xylan, } \\
\text { starch, pectin, } \\
\text { sugars }\end{array}$ & $\begin{array}{l}\text { Lactate, acetate, } \\
\mathrm{H}_{2} \text { and ethanol }\end{array}$ & $50-78(68)$ & $\begin{array}{l}\text { Manure and its } \\
\text { fractions }\end{array}$ & $68 / 55^{\mathrm{a}}$ & Batch & $10-24$ & Nielsen et al. (2007) \\
\hline \multirow[t]{2}{*}{$\begin{array}{c}\text { Caldicellulosiruptor } \\
\text { saccharolyticus } \\
\text { (DSM 8903) }\end{array}$} & $\begin{array}{l}\text { Cellulose, } \\
\text { glycogen, starch, } \\
\text { xylan, sugars }\end{array}$ & $\begin{array}{l}\text { Acetate, lactate } \\
\text { and trace amounts } \\
\text { of ethanol }\end{array}$ & $45-80(70)$ & $\begin{array}{l}\text { Dried green biomass } \\
\text { and tubers, sludge, pig } \\
\text { manure slurry }\end{array}$ & 55 & Batch & ND & Bagi et al. (2007) \\
\hline & & & & $\begin{array}{l}\text { Pig slurry and sweet } \\
\text { sorghum }\end{array}$ & 55 & Reactor (5 L) & $40-42^{b}$ & Kovács et al. (2013) \\
\hline \multirow[t]{2}{*}{$\begin{array}{l}\text { Enterobacter } \\
\text { cloacae (DSM } \\
\text { 16657) }\end{array}$} & Sugars & Acid and $\mathrm{H}_{2}$ & $(30-35)$ & $\begin{array}{l}\text { Dried green biomass } \\
\text { and tubers, sludge, pig } \\
\text { manure slurry }\end{array}$ & 35 & Batch & ND & Bagi et al. (2007) \\
\hline & & & & $\begin{array}{l}\text { Pig slurry and sweet } \\
\text { sorghum }\end{array}$ & 35 & Reactor (5 L) & $33-47^{b}$ & Kovács et al. (2013) \\
\hline $\begin{array}{l}\text { Acetobacteroides } \\
\text { hydrogenigenes } \\
\text { (DSM 24657) }\end{array}$ & $\begin{array}{l}\text { Pectin, starch, } \\
\text { tryptone, yeast } \\
\text { extract, sugars }\end{array}$ & Acetate and $\mathrm{H}_{2}$ & $25-40(37)$ & Corn straw & 37 & Batch & $19-23$ & This study \\
\hline
\end{tabular}

ND, not determined.

a Manure was pretreated with enhanced bacterium at $68^{\circ} \mathrm{C}$, then incubated at $55^{\circ} \mathrm{C}$ for anaerobic digestion.

b Biogas yield. 
slurry. The results showed that the addition of $A$. hydrogenigenes led to a higher methane yield from corn straw or methyl cellulose and xylan (models for cellulose and hemicelluloses, respectively). A proposed mechanism is that hydrogen-producing acetate-type fermentation bacterium promotes more hydrolysates of lignocellulosic biomass, such as C5 and C6 sugars to acetate and hydrogen, and provides a source of energy for the methanogens. The microbiology of anaerobic digestion is complex and delicate. Overall, anaerobic digestion involves four critical steps (hydrolysis, acidogenesis, acetogenesis and methanogenesis) comprised of a sequence of reactions. These complex reactions transpire via a consortium of microorganisms which includes enzyme-secreting, fermentative, $\mathrm{H}_{2}$-consuming, $\mathrm{H}_{2}$-producing, acetogenic, $\mathrm{CO}_{2}$-reducing, and aceticlastic methanogenic bacteria (Appels et al., 2008; Chynoweth and Isaacson, 1987). Organic materials must be decomposed to solutes capable of being actively or passively transported across cell membranes before they can be microbially metabolized. Hydrolysis of complex organic material is regarded as the rate-limiting steps. Presently, most researches have focused on the enrichment of cellulolytic consortia and bioaugmentation for hydrolysis and pretreatment of cellulosic biomass. Comparative bioaugmentation potential of $A$. hydrogenigenes and some species used as enhanced microorganisms are shown in Table 2. Among the fermentative anaerobes, genera Clostridium, Caldicellulosiruptor as well as Enterobacter have been well known as cellulose and hemicelluloses degrading bacteria and extensively studied for bioaugmentation from various organic wastes. Clostridium thermocellum is an anaerobic cellulolytic and hydrogenogenic bacterium, capable of improving methane production by $17-24 \%$ from thermophilic microalgae digestion (Lü et al., 2013). Clostridium cellulolyticum, a cellulolytic bacterium was able to increase methane yield from mesophilic wheat straw digestion by $8-13 \%$ (Peng et al., 2014). A psychrotrophic xylanolytic bacterium Clostridium sp. was found to increase biogas yield by $72 \%$ from cattle manure at $20^{\circ} \mathrm{C}$ (Akila and Chandra, 2010). Caldicellulosiruptor lactoaceticus, an anaerobic thermophilic cellulose and xylan utilizing bacterium was used to pretreat manure, and improved methane production by $10-24 \%$ (Nielsen et al., 2007). These results indicated that cellulolytic and hemicelluloses degrading bacteria can be effective agents for improving methane production by $8-47 \%$ (Table 2 ). The current results are comparable with previous studies, bioaugmentation with acetate-type fermentation bacterium A. hydrogenigenes led to $19-23 \%$ increase of methane yield. Although different fermentation routes are possible, acetate-type fermentation bacterium plays an important role for its abilities to transform soluble sugars into hydrogen and acetate, which can be directly converted to biogas by methanogens. A well-functioning, stable digester had a very low dissolved hydrogen concentration and converts most of the organic substrate to acetic acid (Massé and Droste, 2000). Combined previous studies with this study, it could be assumed that hydrogen producing acetate-type bacterium seems to be an effective procedure for improving methane production from lignocellulosic materials. The fate and dynamics of $A$. hydrogenigenes in the AD process is unclear and require further investigations for future applicability on an industrial scale reactor.

\section{Conclusions}

Principal conclusions are summarized as follows:

(1) A. hydrogenigenes is a hydrogen-producing acetate-type bacterium with a wide range of growth, substrate utilization, relatively high growth rate, high hydrogen yields, substrate and products tolerance. The maximal hydrogen yield was $571 \mathrm{~mL} /$ g-glucose (equivalent to $4.6 \mathrm{~mol} \mathrm{H}_{2} /$ mol glucose) at initial glucose concentration of $1.5 \mathrm{~g} / \mathrm{L}$.
(2) Bioaugmentation with A. hydrogenigenes could increase 19$23 \%$ methane yield of corn straw degradation. The maximum methane yields of $258.1 \mathrm{~mL} / \mathrm{g}$-corn straw was achieved by $10 \%$ inoculum. A. hydrogenigenes could improve the methane yields from methyl cellulose and xylan (models for cellulose and hemicelluloses, respectively) by $16.8 \%$ and $7.0 \%$.

\section{Acknowledgements}

We thank Meng Dai in Qingdao Institute of Bioenergy and Bioprocess Technology for providing the biogas slurry. This work was supported by Taishan Scholar Program of Shandong Province, the National Key Technology R \& D Program (2013BAD22B00), Project of the Chinese Academy of Sciences and Local Cooperation (2012CJT0034), National Science Foundation of China (No. 51108443) and "135" Projects Fund of CAS-QIBEBT Director Innovation Foundation.

\section{Appendix A. Supplementary data}

Supplementary data associated with this article can be found, in the online version, at http://dx.doi.org/10.1016/j.biortech.2014. 12.022 .

\section{References}

Akila, G., Chandra, T.S., 2010. Stimulation of biomethanation by Clostridium sp. PXYL1 in coculture with a Methanosarcina strain PMET1 at psychrophilic temperatures. J. Appl. Microbiol. 108 (1), 204-213.

Appels, L., Baeyens, J., Degrève, J., Bewil, R., 2008. Principles and potential of the anaerobic digestion of waste-activated sludge. Prog. Energy Combust. Sci. 34, 755-781.

Argun, H., Kargi, F., Kapdan, I.K., 2009. Microbial culture selection for bio-hydrogen production from waste ground wheat by dark fermentation. Int. J. Hydrogen Energy 34 (5), 2195-2200.

Bagi, Z., Ács, N., Bálint, B., Horváth, L., Dobó, K., Perei, K.R., Rákhely, G., Kovács, K.L. 2007. Biotechnological intensification of biogas production. Appl. Microbiol. Biotechnol. 76 (2), 473-482.

Chynoweth, D.P., Isaacson, R., 1987. Anaerobic Digestion of Biomass. Elsevier Applied Science Publishers, USA.

Ebringerová, A., Heinze, T., 2000. Xylan and xylan derivatives: biopolymers with valuable properties. 1. Naturally occurring xylans structures, isolation procedures and properties. Macromol. Rap. Commun. 21, 542-556.

Fabiano, B., Perego, P., 2002. Thermodynamic study and optimization of hydrogen production by Enterobacter aerogenes. Int. J. Hydrogen Energy 27, 149-156.

Fantroussi, S.E., Agathos, S.N., 2005. Is bioaugmentation a feasible strategy for pollutant removal and site remediation? Curr. Opin. Microbiol. 8, 268-275.

Fotidis, I.A., Wang, H., Fiedel, N.R., Luo, G., Karakashev, D.B., Angelidaki, I., 2014 Bioaugmentation as a solution to increase methane production from an ammonia-rich substrate. Environ. Sci. Technol. 48 (13), 7669-7676.

Gentry, T.J., Rensing, C., Pepper, I.L., 2004. New approaches for bioaugmentation as a remediation technology. Crit. Rev. Environ. Sci. Technol. 34, 447-494.

Georing, H.D., Van Soest, P.J., 1970. Forage Fiber Analyses (Apparatus, Reagents, Procedures, and Some Applications). Agriculture Handbook, Washington, DC.

Hendriks, A.T.W.M., Zeeman, G., 2009. Pretreatments to enhance the digestibility of lignocellulosic biomass. Bioresour. Technol. 100 (1), 10-18.

Jayasinghearachchi, H.S., Sarma, P.M., Singh, S., Aginihotri, A., Mandal, A.K., Lal, B., 2009. Fermentative hydrogen production by two novel strains of Enterobacter aerogenes HGN-2 and HT 34 isolated from sea buried crude oil pipelines. Int. J. Hydrogen Energy 34 (17), 7197-7207.

Klinke, H.B., Olsson, L., Thomsen, A.B., Ahring, B.K., 2003. Potential inhibitors from wet oxidation of wheat straw and their effect on ethanol production of Saccharomyces cerevisiae: wet oxidation and fermentation by yeast. Biotechnol. Bioeng. 81 (6), 738-747.

Kovács, K.L., Kovács, Á.T., Maróti, G., Bagi, Z., Csanádi, G., Perei, K., Bálint, B., Balogh, J., Fülöp, A., Mészáros, L.S., Tóth, A., Dávid, R., Latinovics, D., Varga, A., Rákhely, G., 2004. Improvement of biohydrogen production and intensification of biogas formation. Rev. Environ. Sci. Biotechnol. 3 (4), 321-330.

Kovács, K.L., Ács, N., Kovács, E., Wirth, R., Rákhely, G., Strang, O., Herbel, Z., Bagi, Z., 2013. Improvement of biogas production by bioaugmentation. Biomed. Res. Int. 2013, 1-7.

Lü, F., Ji, J.Q., Shao, L.M., He, P.J., 2013. Bacterial bioaugmentation for improving methane and hydrogen production from microalgae. Biotechnol. Biofuels 6 (92), $1-11$.

Massé, D.I., Droste, R.L., 2000. Comprehensive model of anaerobic digestion of swine manure slurry in a sequencing batch reactor. Water Res. 34 (12), 3087-3106. 
J. Zhang et al./Bioresource Technology 179 (2015) 306-313

313

McDonald, P., Edwards, R.A., 1976. The influence of conservation methods on digestion and utilization of forages by ruminants. Proc. Nutr. Soc. 35, 201-211.

Mösche, M., Jördening, H.J., 1999. Comparison of different models of substrate and product inhibition in anaerobic digestion. Water Res. 33 (11), 2545-2554.

Nielsen, H.B., Mladenovska, Z., Ahring, B.K., 2007. Bioaugmentation of a two-stage thermophilic $\left(68^{\circ} \mathrm{C} / 55^{\circ} \mathrm{C}\right)$ anaerobic digestion concept for improvement of the methane yield from cattle manure. Biotechnol. Bioeng. 97 (6), 1638-1643.

Peng, X., Börner, R.A., Nges, I.A., Liu, J., 2014. Impact of bioaugmentation on biochemical methane potential for wheat straw with addition of Clostridium cellulolyticum. Bioresour. Technol. 152, 567-571.

Qiao, J.T., Qiu, Y.L., Yuan, X.Z., Shi, X.S., Xu, X.H., Guo, R.B., 2013. Molecular characterization of bacterial and archaeal communities in a full-scale anaerobic reactor treating corn straw. Bioresour. Technol. 143, 512-518.

Qiu, Y.L., Kuang, X.Z., Shi, X.S., Yuan, X.Z., Guo, R.B., 2014. Terrimicrobium sacchariphilum gen. nov., sp. nov., an anaerobic bacterium of the class 'Spartobacteria' in the phylum Verrucomicrobia, isolated from a rice paddy field. Int. J. Syst. Evol. Microbiol. 64, 1718-1723.

Sekiguchi, Y., Kamagata, Y., Nakamura, K., Ohashi, A., Harada, H., 2000. Syntrophothermus lipocalidus gen. nov., sp. nov., a novel thermophilic, syntrophic, fatty-acid-oxidizing anaerobe which utilizes isobutyrate. Int. J. Syst. Evol. Microbiol. 50, 771-779.

SEPA, 2002. Monitor and Analysis Method of Water and Wastewater. Chinese Environmental Science Publication House, Beijing.

Su, X.L., Tian, Q., Zhang, J., Yuan, X.Z., Shi, X.S., Guo, R.B., Qiu, Y.L., 2014. Acetobacteroides hydrogenigenes gen. nov., sp. nov., an anaerobic hydrogenproducing bacterium in the family Rikenellaceae isolated from a reed swamp. Int. J. Syst. Evol. Microbiol. 64, 2986-2991.
Wang, X.J., Ren, N.Q., Xiang, W.S., Guo, W.Q., 2007. Influence of gaseous endproducts inhibition and nutrient limitations on the growth and hydrogen production by hydrogen-producing fermentative bacterial B49. Int. J. Hydrogen Energy 32, 748-752.

Wang, Y.Y., Zhang, Y.L., Wang, J.B., Meng, L., 2009. Effects of volatile fatty acid concentrations on methane yield and methanogenic bacteria. Biomass Bioenergy 33 (5), 848-853.

Wang, H., Vuorela, M., Keränen, A.L., Lehtinen, T.M., Lensu, A., Lehtomäki, A., Rintala, J., 2010. Development of microbial populations in the anaerobic hydrolysis of grass silage for methane production. FEMS Microbiol. Ecol. 72 (3), 496-506.

Weiß, S., Tauber, M., Somitsch, W., Meincke, R., Müller, H., Berg, G., Guebitz, G.M., 2010. Enhancement of biogas production by addition of hemicellulolytic bacteria immobilised on activated zeolite. Water Res. 44 (6), 1970-1980.

Wilde, E., Collins, M.D., Hippe, H., 1997. Clostridium pascui sp. nov., a new glutamate-fermenting sporeformer from a pasture in Pakistan. Int. J. Syst. Bacteriol. 47, 164-170.

Wu, Y.R., He, J.Z., 2013. Characterization of anaerobic consortia coupled lignin depolymerization with biomethane generation. Bioresour. Technol. 139, 5-12.

Yan, L., Gao, Y.M., Wang, Y.J., Liu, Q., Sun, Z.Y., Fu, B.R., Wen, X., Cui, Z.J., Wang, W.D., 2012. Diversity of a mesophilic lignocellulolytic microbial consortium which is useful for enhancement of biogas production. Bioresour. Technol. 111, 49-54.

Yuan, X.Z., Shi, X.S., Zhang, P.D., Wei, Y.L., Guo, R.B., Wang, L.S., 2011. Anaerobic biohydrogen production from wheat stalk by mixed microflora: kinetic model and particle size influence. Bioresour. Technol. 102 (19), 9007-9012. 